\title{
CONSONANT ALLITERATION IN OVID'S METAMORPHOSES, BOOKS IX-XV
}

ABSTRACT: In Book IX T, D alliteration amounts to $21,8 \%, \mathbf{M}, \mathbf{N}-16,8 \%$, in Book $\mathrm{X}$ the most frequent alliteration is $\mathbf{T}, \mathbf{D}-21,2 \%$, then $\mathbf{M}, \mathbf{N}-12,9 \%$. In Book XI the first place belongs to alliteration $\mathbf{T}, \mathbf{D}-14,08 \%, \mathbf{M}, \mathbf{N}-13,7 \%$. In Book $\mathrm{XII}$ it is $\mathbf{M}, \mathbf{N}$ alliteration that prevails $-16,4 \%$, next we have $\mathbf{T}, \mathbf{D}-12,7 \%$. In Book XIII the first place goes back to $\mathbf{T}, \mathbf{D}$ alliteration $-17,8 \%$, then we have $\mathbf{M}$, $\mathbf{N}-14,8 \%$. In Book XIV, the same as in Book XII, the predominant alliteration is $\mathbf{M}, \mathbf{N}-22,2 \%$, followed by $\mathbf{T}, \mathbf{D}-19,5 \%$. The same tendency is also apparent in Book XV, with the most numerous alliteration being $\mathbf{M}, \mathbf{N}-22,5 \%$, followed by T, D $-22,4 \%$. The most important alliterations play a variety of roles in Books IX-XV. They describe the metamorphoses, e. g. Iphis changing into a man, Hippomenes and Atalanta into a lion, Acmon into a bird etc. They express great passions and the death of the protagonists. The alliteration clusters are found in the apotheosis of Romulus and Augustus, as well as the immortality of Heracles. Ovid uses them to describe the elements, such as the flood or sea storm, and powerful animals.

KEY WORDS: alliteration T, D, M, N, clusters, metamorphoses, great passions, the death of the protagonists, the apotheosis of Romulus and Augustus, the elements, the animals 
According to my calculations, in Book IX the most frequent alliteration is $\mathbf{T}, \mathbf{D} .{ }^{1}$ It appears in 174 verses, out of total 797. In 12 passages it is grouped, forming so-called clusters (v. 85, 86, 89, 91; 95, 97, 98; $124,127,128 ; 143,145,146 ; 168,169,171,172 ; 208,209,211 ; 375$, 376, 377, 378, 379, 381; 403, 405, 407, 408; 426, 427, 428; 483, 484, $486 ; 542,545,547,549 ; 792,793,795) .{ }^{2}$ I will point to nine examples which I deem the most important and unquestionable: v. 215: palliDus eT TimiDe verba excusanTia DiciT; v. 324: DixiT eT aDmoniTu veTeris commoTa minisTrae; v. 353: ToTaque paulaTim lenTus premiT inguina corTex; v. 379: eT TrisTis DicaT: "laTeT hoc in sTipiTe maTer"; v. 443: Tunc eraT invaliDus DeioniDenque iuvenTae; v. 524: eT noTaT eT DeleT; muTaT culpaTque probaTque; v. 572: omine TurbaTa esT, misiT Tamen. apTa minisTer; v. 573: Tempora nacTus adiT TraDiTque laTenTia verba; v. 625: pecTora nosTra, Deo, seD vicTa libiDine creDar!

Another alliteration to consider is $\mathbf{M}, \mathbf{N}$. In Book IX it appears in 135 verses, including 8 clusters (v. 116, 118, 119; 129, 130, 131; 250, 251,$253 ; 280,281,282,283,284 ; 488,489,490 ; 608,609,610 ; 666$, $667,669,670,671 ; 734,735,737,739)$. Let me point out the three most important passages: v. 326: "te taMeN, o geNetrix, alieNae saNguiNe Nostro; v. 361: cresceNteM truNcuM raMosque aMplexa Morabar; v. 694: pleNaque soMNiferis serpeNs peregriNa veNeNis.

The third most frequent alliteration is $\mathbf{S}$. It can be found in 31 verses; there are no clusters. One verse is particularly expressive, namely v. 691: Sanctaque BubaStiS variuSque coloribuS ApiS.

I have identified examples of $\mathbf{R}$ alliteration in 30 verses, with no clusters. Two verses I deem deserving of the reader's attention: v. 345: decideRe et tRemulo Ramos hoRRoRe moveRi; v. 713: sive daRes pueRo, fieRet foRmosus uteRque.

$\mathbf{L}$ alliteration appears in 18 verses, without any clusters; one verse might be quoted: v. 161: incaLuit vis iLLa maLi resoLutaque fLammis.

$\mathbf{M}, \mathbf{N}, \mathbf{T}, \mathbf{D}$ alliteration can be found in 3 verses, there are no clusters or any striking examples. C, G, QU alliteration appears in 4 verses, also

The text of Ovid's Metamorphoses I use is based on the edition P. Ovidii Nasonis Metamorphoses, edidit William S. Anderson, Bibliotheca Scriptorum Graecorum et Romanorum Teubneriana, Leipzig 1991.

2 The most impressive clusters will be discussed separately in the latter part of this paper. 
without clusters and interesting passages. In Book IX I have also noticed intensive alliterations appearing solely in isolated verses, for example $\mathbf{B}$, v. 763: sacra, quiBus qui ducat aBest, uBi nuBimus amBae?"; T, D, R, v. 192: ARcaDiae vasTaToR apeR, nec pRofuiT hyDRae.

Let me now discuss Book X. Here, the most frequent alliteration is T, D, which appears in 157 verses out of total 739 verses in the book. There are 17 clusters (v. 9, 10, 12; 71, 72, 73; 174, 175, 177; 180, 181, $183 ; 256,257,258,259 ; 345,346,347 ; 370,371,372,374 ; 423,425$, 426; 461, 462, 463, 464; 517, 518, 519; 541, 542, 543, 544; 582, 584, 585,$586 ; 598,599,602 ; 612,615,616,618 ; 622,623,624,625 ; 706$, $707,709,710 ; 723,724,725)$. Ten verses are particularly noteworthy: v. 202: aTque uTinam pro Te viTam Tecumque licereT; v. 389: muTa sileT virgo Terramque inmoTa TueTur; v. 445: seD Tamen eT gauDeT: TanTa esT DiscorDia menTis; v. 446: Tempus eraT, quo cuncTa silenT, inTerque Triones; v. 482: aTque inTer morTisque meTus eT TaeDia viTae; v. 500: fleT Tamen, eT TepiDae mananT ex arbore guTTae; v. 585: inTempTaTa mihi forTuna relinquiTur?" inquiT; v. 598: eT TegiTur fesTa vicTrix ATalanTa corona; v. 662: specTaTosque Diu vulTus inviTa reliquiT!; v. 709: carpiT iTer, seD sTaT moniTis conTraria virTus.

The second most frequent alliteration is $\mathbf{M}, \mathbf{N}$. It can be found in 113 verses, there are 9 clusters (v. 15, 16, 18; 32, 34, 35; 45, 46, 47; 266, 267, 269, 271; 300, 301, 304; 338, 339, 340, 342, 343; 414, 415, $416,418 ; 700,701,704,705 ; 718,719,721)$, four verses deserve to be quoted: v. 35: huMaNi geNeris loNgissiMa regNa teNetis; v. 296: corNibus iN pleNuM NovieNs luNaribus orbeM; v. 404: MeNte Nefas aliqueMque taMeN praeseNtit aMoreM; v. 487: Mutataeque Mihi vitaMque NeceMque Negate".

Instances of $\mathbf{S}$ alliteration are abundant as well. They appear in 52 verses, yet there are no clusters. Two verses are extremely striking: v. 483: eSt taleS conpleXa preceS: "o Siqua patetiS; v. 540: raptoreSque lupoS armatoSque unguibuS urSoS.

I have found $\mathbf{L}$ alliteration in 32 verses, without any cluster; one verse in particular draws attention: v. 519: Labitur occuLte faLLitque voLatiLis aetas.

$\mathbf{R}$ alliteration can be identified in 26 verses, there is one cluster (v. 592, 594, 595) and one very interesting example: v. 137: in viRidem veRti coepeRunt membRa coloRem. 
$\mathbf{C}, \mathbf{G}$ alliteration occurs in 9 verses, there are no clusters, one verse is noteworthy: v. 43: neC Carpsere ieCur voluCres, urnisQUe vaCarunt.

There are also some minor alliterations. $\mathbf{M}, \mathbf{N}, \mathbf{T}, \mathbf{D}$ alliteration appears in 4 verses, similar to $\mathbf{V}$, while $\mathbf{S}, \mathbf{T}, \mathbf{D}$ alliteration can be found in 3 passages and $\mathbf{R}, \mathbf{M}, \mathbf{N}$ in 2 .

In Book XI the most frequent alliteration is T, D. It appears in 112 verses, out of total 795. There are 6 clusters (v. 22, 23, 24, 25, 27; 59, 60, $61 ; 75,77,78,79 ; 374,375,376 ; 553,555,556 ; 709,710,713,714,715$, 717), while six passages are particularly striking: v. 59: arceT eT in lapiDem ricTus serpenTis aperTos; v. 60: congelaT eT paTulos, uT eranT, inDuraT hiaTus; v. 250: "AeaciDe", DixiT "THalamis poTiere peTiTis; v. 311: uT sua maTurus conpleviT Tempora venTer; v. 314: canDiDa De nigris eT De canDenTibus aTra; v. 758: Tempora sorTiTus. fraTer fuiT HecToris isTe.

$\mathbf{M}, \mathbf{N}$ alliteration can be found in 109 verses, there are 4 clusters (v. 284, 285, 286; 378, 380, 381, 382; 563, 565, 566, 567; 704, 705, 706, 707), two verses warrant particular attention: v. 328: quaM Miser (o pietas!) ego tuM patriuMque doloreM; v. 361: Nereides Nereusque teNeNt; hos Navita poNti.

I found $\mathbf{S}$ alliteration in 57 verses, with no clusters; five verses should be quoted: v. 114: HeSperidaS donaSSe puteS; Si poStibuS altiS; v. 299: illiuS virtuS regeS genteSque Subegit; v. 481: fluctibuS et praecepS Spirare valentiuS euruS; v. 733: Stringebat SummaS aleS miSerabiliS undaS; v. 770: iniectoS umeriS Siccantem Sole capilloS.

$\mathbf{L}$ alliteration is present in 35 verses, there are no clusters, one verse is noteworthy: v. 611: pLumeus, unicoLor, puLLo veLamine tectus.

I observed $\mathbf{R}$ alliteration in 27 verses, with neither clusters nor any particularly striking examples. C, $\mathbf{Q}$ alliteration appears in 7 verses, there are no clusters. F, PH alliteration can be found in 3 verses, while $\mathbf{T}, \mathbf{D}, \mathbf{S}$ in 2 .

The principal alliteration in Book XII is $\mathbf{M}, \mathbf{N}$. It appears in 103 verses out of total 628 . There are 6 clusters (v. 230, 231, 232; 260, 261, 263,$264 ; 315,316,318 ; 453,454,456,459,460,461 ; 467,468,470$, $471 ; 501,503,504,506)$, two verses are interesting enough to be quoted: v. 28: saNguiNe virgiNeo placaNdaM virgiNis iraM; v. 275: arseruNt criNes, et vulNere saNguis iNustus. 
Suprisingly, T, D alliteration is less frequent in this book. I noted its presence in 80 verses, with 3 clusters (v. 93, 94, 96; 276, 278, 279; 340, 342, 343, 345); four verses warrant special attention: v. 47: ToTa fremiT vocesque referT iTeraTque, quoD auDiT; v. 85: uTque hebeTi pecTus TanTummoDo conTuDiT icTu; v. 286: "ceTera siT forTis casTrorum Turba Tuorum!"; v. 625: LaerTiaDaeque fuiT TanTae fiDucia lauDis.

$\mathbf{S}$ alliteration can be seen in 50 verses, there is one cluster (v. 235, 236, 237), while four verses are noteworthy: v. 319: fuSuS in OSSaeae villoSiS pellibuS urSae; v. 541: nubigenaS domitoS a Se pater eSSe Solebat"; v. 562: viribuS uSuS aviS penniS roStroque redunco; v. 627: ArgolicoSque duceS mediiS conSidere caStriS.

$\mathbf{L}$ alliteration is present in 35 verses, there are no clusters; I quote three verses: v. 408: CyLLaron una tenet; cuLtus quoque, quantus in iLLis; v. 537: proeLia TLepoLemus PyLio referente doLorem; v. 592: cum tamen iLLe ferox beLLoque cruentior ipso.

I identified instances of $\mathbf{R}$ alliteration in 30 verses, with neither clusters nor any verses important to quote.

$\mathbf{C}, \mathbf{G}$ alliteration can be found in 9 verses, without any clusters. $\mathbf{V}$ alliteration appears in 4 verses, with no clusters, $\mathbf{L}, \mathbf{T}, \mathbf{D}$ in 3 , and $\mathbf{M}, \mathbf{N}$, $\mathbf{C}, \mathbf{G}$ in 2, similar to $\mathbf{L}, \mathbf{M}, \mathbf{N}$.

Let me now discuss Book XIII. In contrast to the preceding book, I observed that here $\mathbf{T}, \mathbf{D}$ is the most frequent alliteration. It can be found in 173 verses, out of total 968 . There are 12 clusters (v. 36, 38, 39; 81, 82, 83,84 ; 220, 221, 223, 227, 228, 230; 236, 237, 238, 239; 378, 379, 381; 410, 411, 412; 521, 522, 524; 551, 554, 555, 556, 557, 559, 560, 561; $580,581,582 ; 589,591,593,594 ; 871,872,874 ; 899,901,902,904)$, ten verses should be quoted: v. 116: TarDa fuTura Tibi esT gesTamina TanTa TrahenTi; v. 334: Tamque Tuis poTiar, faveaT ForTuna, sagiTTis; v. 446: obruTaque esT mecum virTuTis graTia nosTrae?; v. 452: DuciTur aD Tumulum Diroque fiT hosTia busTo; v. 515: maTernos lucTus, hosTilia busTa piasTi!; v. 624: spem quoque faTa sinunT; sacra eT, sacra alTera, paTrem; v. 661: eT ToTiDem naTis AnDros fraTerna peTiTa esT; v. 678: qui peTere anTiquam maTrem cognaTaque iussiT; v. 899: DisceDunT placiDisque naTanT NereiDes unDis; v. 937: eT muTare laTus Terraque $\mathrm{uT}$ in aequore niTi.

$\mathbf{M}, \mathbf{N}$ alliteration can be observed in 144 verses, there are 9 clusters (v. 96, 98, 99, 100; 254, 256, 257, 258, 260; 303, 304, 306; 364, 367, 
$368 ; 462,463,464,465 ; 645,646,647 ; 818,819,821 ; 832,833,834$; $838,839,840,841)$, while four verses I would particularly recommend to the reader: v. 653: iN segeteM laticeMque Meri caNaeque MiNervae; v. 665: NoN hic AeNeas, NoN, qui defeNderet ANdroN; v. 812: Nec seNtitur hieMs; suNt poMa gravaNtia raMos; v. 923: NuNc iN Mole sedeNs Moderabar haruNdiNe liNuM.

S alliteration appears in 79 verses, there are no clusters, seven verses deserve to be quoted: v. 15: quae Sine teSte gerit, quorum noX conScia Sola eSt; v. 274: TroaS ab arSuriS cum defenSore cariniS; v. 327: AiaciS Stolidi DanaiS Sollertia proSit; v. 438: eXanimem Scopulo SubiectaS miSit in undaS; v. 572: illiuS TroaSque SuoS hoSteSque PelaSgoS; v. 608: inSonuit penniS; pariter Sonuere SororeS; v. 892: oSque cavum SaXi Sonat eXSultantibuS undiS.

L alliteration can be observed in 47 verses, with two clusters (v. 458, 460, 461; 794, 795, 796) and three verses of particular note: v. 460: "sciLicet haud uLLi servire PoLyxena veLLem; v. 771: TeLemus Eurymides, quem nuLLa fefeLLerat aLes; v. 862: iLLe tamen pLaceatque sibi pLaceatque Licebit.

I identified instances of $\mathbf{R}$ alliteration in 32 verses, there are no clusters, two verses are worthy to be quoted: v. 359: MeRiones, peteRet maioRis fRateR AtRidae; v. 568: moRsibus insequituR Rictuque in veRba paRato.

$\mathbf{C}, \mathbf{G}$ alliteration appears in 13 verses, without any clusters, but with two interesting examples: v. 639: munera Cum liQUido Capiunt Cerealia BaCCHo; v. 480: Cum Caderet, CastiQUe deCus servare pudoris.

$\mathbf{M}, \mathbf{N}, \mathbf{T}, \mathbf{D}$ alliteration can be found in 8 verses, with neither clusters nor any particularly striking examples.

$\mathbf{V}$ alliteration appears in 5 verses, without any clusters, $\mathbf{L}, \mathbf{T}, \mathbf{D}$ in 3, whereas R, T, D; L, M, N; T, D, S; L, T; and $\mathbf{F}$ in 2 each. Out of the alliterations appearing only once in the whole book I would like to point out the $\mathbf{T}, \mathbf{V}$ alliteration in verse 251: aTque iTa capTiVo VicTor VoTisque poTiTus.

In Book XIV the first place (as far as frequency is concerned) belongs firmly to $\mathbf{M}, \mathbf{N}$ alliteration. It appears in 189 verses, out of total 851 . There are 17 clusters (v. 33, 34, 35; 138, 139, 140, 141, 142, $144 ; 147,148,149 ; 165,167,168 ; 200,201,202,203,204 ; 262,264$, $265 ; 310,312,313,314 ; 427,429,430 ; 441,442$, 443; 492, 493, 494; 
503, 505, 506, 509, 511, 512; 578, 579, 581; 702, 703, 705; 724, 725, $726 ; 760,761,762 ; 787,788,789 ; 809,810,812,813)$, while twelve verses deserve a closer look: v. 182: iNMaNeM scopuluM Medias perMisit iN uNdas; v. 201: MeMbraque et huMaNo coNcretaM saNguiNe barbaM; v. 202: Mors erat aNte oculos, MiNiMuM taMeN ipsa doloris; v. 211: MaNdeNteMque videNs eiectaNteMque crueNtas; v. 252: EurylochuMque siMul NiMiique ElpeNora viNi; v. 308: aNNua Nos illic teNuit Mora, Multaque praeseNs; v. 503: iNdurata rigeNt fiNeMque iN acuMiNe poNuNt; v. 512: hacteNus OeNides; VeNulus CalydoNia regNa; v. 554: liNa coMae Molles, aNteMNae bracchia fiuNt; v. 694: IdalieN MeMoreMque tiMe RhaMNusidis iraM; v. 751: Mota taMeN "videaMus" ait "Miserabile fuNus"; v. 845: Nec Mora, RoMuleos cuM virgiNe ThauMaNtea.

T, D alliteration appears as well with great frequency, as it can be found in 166 verses. There are 11 clusters (v. 276, 278, 279; 293, 294, 296, 297; 571, 573, 574; 593, 594, 595, 596, 598; 605, 607, 608, 611; $619,620,621 ; 653,654,656,657 ; 687,688,689 ; 755,756,758 ; 804$, $805,807 ; 832,833,835)$ and five verses of particular interest: v. 196: guTTur eT elisi TrepiDenT sub DenTibus arTus; v. 297: inDe fiDes DexTraeque DaTae, THalamoque recepTus; v. 455: eT mulTi RuTulos, mulTi Troiana TuenTur; v. 611: quo saTus anTiquo TenuiT repeTiTa LaTinus; v. 739: ic Ta peDum moTu TrepiDanTem eT $\dagger$ mulTa TimenTEm $\dagger$.

$\mathbf{S}$ alliteration can be observed in 83 verses, there are 3 clusters (v. 207, 208, 210; 266, 267, 268; 400, 402, 403) and four verses which deserve closer inspection: v. 92: Cercopum eXoSuS gentiSque admiSSa doloSae; v. 320: PicuS in AuSoniiS, proleS Saturnia, terriS; v. 481: quoS communiS hiemS inportunuSque CaphereuS; v. 556: illaS virgineiS eXercent luSibuS undaS.

I identified instances of $\mathbf{R}$ alliteration in 45 verses, without any clusters; let me quote two verses: v. 437: RuRsus iniRe fRetum, RuRsus daRe vela iubemuR; v. 468: NaRyciusque heRos, a ViRgine viRgine Rapta.

Slightly less frequent is $\mathbf{L}$ alliteration. It appears in 38 verses, with no clusters; one verse is noteworthy: v. 255: miLLe Lupi mixtique Lupis ursique Leaeque.

C, G (Q) alliteration can be found in 14 verses, there are no clusters; $\mathbf{M}, \mathbf{N}, \mathbf{T}, \mathbf{D}$ appears in 11 verses, with no clusters; $\mathbf{L}, \mathbf{M}, \mathbf{N}$ in 5, again 
without clusters; $\mathbf{S}, \mathbf{D}, \mathbf{T}$ in 4 verses, without any clusters; $\mathbf{S}, \mathbf{M}, \mathbf{N}$ in 3, $\mathbf{V}$ in 3, $\mathbf{C}, \mathbf{D}, \mathbf{T}$ in 3 - let me quote one: v. 522: aDDiDiT obsCenis ConviCia rusTiCa DicTis; $\mathbf{M}, \mathbf{N}, \mathbf{R}$ in 2, $\mathbf{R}, \mathbf{T}, \mathbf{D}$ in $2, \mathbf{S}, \mathbf{L}$ in $2, \mathbf{B}$ in 2, $\mathbf{R}$, and $\mathbf{S}$ in 2.

Finally, I proceed to discuss Book XV. Here again the most frequent alliteration is $\mathbf{M}, \mathbf{N}$. It can be found in 198 verses, out of total 879 . There are 17 clusters (v. 44, 46, 47; 83, 84, 85, 87; 194, 196, 197; 257, 258, 259 ; 295, 297, 298; 309, 311, 312, 313; 350, 352, 353, 354; 390, 391, 393 ; 431, 432, 433, 434; 450, 451, 453, 456, 457, 458, 459; 490, 491, $493,495,496 ; 545,546,547,548 ; 555,556,558 ; 563,565,566 ; 724$, $725,726 ; 755,756,758 ; 837,838,840)$ and five verses which I believe are particularly important: v. 102: cuNcta siNe iNsidiis NullaMque tiMeNtia fraudeM; v. 178: cuNcta fluuNt, oMNisque vagaNs forMatur iMago; v. 210: Maturus Mitisque iNter iuveNeMque seNeMque; v. 279: Nec NoN SicaNias volveNs AMeNaNus hareNas; v. 658: "poNe Metus! veNiaM siMulacraque Nostra reliNquaM.

Almost equal in number is T, $\mathbf{D}$ alliteration. It appears in 197 verses, there are 10 clusters (v. 24, 25, 26, 27, 29, 30; 203, 205, 206; 269, 271, 272 ; 411, 412, 414, 415; 465, 467, 468, 469; 682, 684, 685, 686, 687, $690,691,692,695,696,697 ; 701,702,704 ; 761,762,764,765,766$, $767 ; 829,831,832,835)$ and eight verses which should be quoted here: v. 108: (iDque saTis fueraT) nosTrumque peTenTia leTum; 148: asTra, iuvaT Terris eT inerTi seDe relicTa; v. 200: aDspicis, aeTaTis peragenTem imiTamina nosTrae?; v. 249: inDe reTro reDeunT, iDemque reTexiTur orDo; v. 517: quaDripeDes monsTrique meTu TurbanTur eT alTis; v. 551: feciT eT aeTernas arTus TenuaviT in unDas; v. 735: icTaqueconiecTos incalfaciT hosTia culTros; v. 835: Temporis aeTaTem venTurorumque nepoTum.

I found $\mathbf{S}$ alliteration in 103 verses. There are 4 clusters (v. 231, 232, $234 ; 245,246,248 ; 819,820,821,822 ; 855,856,857)$ and eight verses of great interest: v. 134: quaS coluit, frugeS percuSSaque Sanguine cultroS; v. 320: AethiopeSque lacuS? quoS SiquiS faucibuS hauSit; v. 512: pectoribuSque tenuS molleS erectuS in auraS; v. 715: VolturnuS niveiSque frequenS SinueSSa colubriS; v. 739: Scinditur in geminaS parteS circumfluuS amniS; v. 752: Scilicet aequoreoS pluS eSt domuiSSe BritannoS; v. 754: victriceS egiSSe rateS NumidaSque rebelleS; v. 757: et multoS meruiSSe, aliquoS egiSSe triumphoS. 
$\mathbf{R}$ alliteration can be noted in 38 verses, with no clusters; one verse is worthy of a quote: v. 652: umbRaque telluRis tenebRas induxeRat oRbi.

$\mathbf{M}, \mathbf{N}, \mathbf{T}, \mathbf{D}$ alliteration appears in 25 verses, without any clusters; one verse deserves particular attention: v. 602: auT fiNiTe MeTuM faTalis MorTe TyraNNi".

$\mathbf{L}$ alliteration can be found in 20 verses, there are no clusters.

I identified instances of $\mathbf{C}, \mathbf{G}(\mathbf{Q}, \mathbf{C H})$ alliteration in 16 verses, without any clusters.

$\mathbf{N}, \mathbf{M}, \mathbf{S}$ alliteration appears in 7 verses, one is especially interesting, v. 797: NocturNoS ululaSSe caNeS uMbraSque SileNtuM; S, T, D and $\mathbf{V}$ alliterations have similar frequency. $\mathbf{M}, \mathbf{N}, \mathbf{R}$ alliteration can be found in 6 verses, with no clusters and one verse which should be considered more closely: v. 620: corNuaque aeRatis MiRaM RefeRentia foRMaM. $\mathbf{L}, \mathbf{M}, \mathbf{N}$ alliteration appears in 3 verses, similar to $\mathbf{T}, \mathbf{D}, \mathbf{L}$ and $\mathbf{P} . \mathbf{P}, \mathbf{M}$, $\mathbf{N} ; \mathbf{R}, \mathbf{T}$ and $\mathbf{L}, \mathbf{T}$ alliterations are found in 2 verses each. There are also some alliterations which appear only once in the whole book: $\mathbf{S}$, P, R, v. 378: PoSteRioR SuPeRat PaRteS menSura PRioReS; T, D, R, v. 516: aD fReTa conveRTunT aDRecTisque auRibus hoRRenT; and R, T, v. 860: TeRRa sub AugusTo esT; paTer esT eT RecToR uTeRque.

Let me now present the major alliterations in percentages. As in books I-VIII, the most frequent alliterations are $\mathbf{T}, \mathbf{D}$ and $\mathbf{M}, \mathbf{N}$. When it comes to precise numbers, the situation looks as follows. In Book IX $\mathbf{T}, \mathbf{D}$ alliteration amounts to $21,8 \%, \mathbf{M}, \mathbf{N}-16,8 \%, \mathbf{S}-3,8 \%, \mathbf{R}-3,7 \%$. In Book $\mathrm{X}$ the most frequent alliteration is $\mathbf{T}, \mathbf{D}-21,2 \%$, then $\mathbf{M}, \mathbf{N}-$ $12,9 \%, \mathbf{S}-7,03 \%, \mathbf{L}-4,3 \%$. In Book XI the first place belongs to T, $\mathbf{D}$ alliteration, with $14,08 \%$, then $\mathbf{M}, \mathbf{N}-13,7 \%, \mathbf{S}-7,1 \%, \mathbf{L}-4,4 \%$. In Book XII it is $\mathbf{M}, \mathbf{N}$ alliteration that prevails $-16,4 \%$, next we have T, D $-12,7 \%, \mathbf{S}-7,9 \%, \mathbf{L}-5,5 \%$. In Book XIII the first place goes back to $\mathbf{T}$, D alliteration $-17,8 \%$, then we have $\mathbf{M}, \mathbf{N}-14,8 \%, \mathbf{S}-8,1 \%, \mathbf{L}-4,8 \%$. In Book XIV, the same as in Book XII, the predominant alliteration is $\mathbf{M}, \mathbf{N}-22,2 \%$, followed by $\mathbf{T}, \mathbf{D}-19,5 \%, \mathbf{S}-9,7 \%, \mathbf{R}-5,2 \%$. The same tendency is also apparent in Book XV, with the most numerous alliteration being $\mathbf{M}, \mathbf{N}-22,5 \%$, followed by $\mathbf{T}, \mathbf{D}-22,4 \%, \mathbf{S}-11,7 \%$, $\mathbf{R}-4,3 \%$.

The time has now come to answer the question of the specific role that alliteration plays in books IX-XV. I intend to proceed in a manner similar to the one in my analysis of books I-VIII, i.e. to take into 
consideration only those instances which I refer to as clusters, that is those passages where a given alliteration pattern recurs in several subsequent verses. I shall start with a discussion of $\mathbf{T}, \mathbf{D}$ alliteration in Book IX. Verses 85-91 and 95-98 tell the story of the fight between Achelous and Heracles, which resulted in the creation of the famous cornucopia. In verses 124-128 the narrator describes the death of the centaur Nessus, killed by Heracles. A bit further on Deianira bemoans the fact that Heracles fell in love with Iole (v. 143-146). Verses 168-172 tell of Heracles' cruel death, especially v. 170-171:

ipse cruor, gelido ceu quondam lammina candens

tincta lacu, stridit coquiturque ardente veneno.

Heracles' pain-induced ravings fill verses 208-210. A longer passage (v. 375-381) describes the unexpected metamorphosis of Dryope into a tree. The prophecy of Themis on Polynices and Eteocles is recounted in verses 403-408. Byblis' dreams are described in 483-486. A little further on she makes a dramatic confession of her love to her own brother (v. 542-549). In verses 792-795 we read about the fortuitous metamorphosis of Iphis into a man.

I shall pass now to the discussion of alliteration $\mathbf{M}, \mathbf{N}$. Nessus' attempt to kidnap Deianira is described in verses 116-119, while the account of his death can be found in 129-131. Jupiter foretells Heracles' immortality (v. 250-253). In verses 280-284 we read about Alcmene's confession to Iole. Byblis rhetorical questions appear in verses 488-490. Ovid brings us back to Byblis and her further dilemma in verses 608-610. In verses 666-671 we are reminded of the miraculous metamorphosis of Iphis, by grace of a goddess. Iphis is aware of her mad passion (v. 735-739):

meus est furiosior illo, si verum profitemur, amor.

Let me begin the discussion of book $\mathrm{X}$ with the $\mathbf{T}, \mathbf{D}$ alliteration in verses 9-12, where we read of Eurydice bitten by a snake and Orpheus' despair. The otherwise unknown story of Olenus and Lethaea and their transformation into rocks on the humid mountain Ida is described in verses $71-73$. Verses $174-177$ and 180-183 bring the news 
of Hyacinth's tragic death. Pygmalion's unusual love for the statue of a beautiful woman he sculpted himself is told in verses 256-259. Myrrha's unnatural love for her father Cinyras is depicted in verses 345-347 and 370-374:

\section{carpitur indomito furiosaque vota retractat}

et modo desperat, modo vult temptare, pudetque

et cupit et, quid agat, non invenit (...).

Myrrha's story is continued in verses 423-426. The old nurse is shaking out of pure terror, with white hair stiffened on her head. Unfortunately, the incestuous passion is fulfilled in verses 461-464. Another example: Venus warns Adonis against excessive bravery (v. 541-544). Hippomenes falls in love with Atalanta in verses 582-586. A little further (v. 598-602) we learn of the cruel punishment that awaits all who are defeated by Atalanta in a footrace and of Hippomenes' courage. Atalanta wonders what motivates Hippomenes to challenge her. She is moved neither by his beauty nor his youth (v. 612-618). Atalanta's thoughts are expounded upon in the following verses of the book (v. 622-625). Next, Venus warns Adonis that his bravery might bring bad fortune upon them both and flies away in a chariot drawn by swans (v. 706-709). We learn how Venus despaired after Adonis died in verses 723-725.

I shall pass now to the discussion of accumulated $\mathbf{M}, \mathbf{N}$ alliteration in Book X, starting with verses 15-18. They tell us of Orpheus who has approached Persephone's throne and the realm of Dis. Orpheus recalls that all people belong wholly to the subterranean world and their life on the surface is nothing but a brief moment. The gods rule long over the people (v. 32-35). The music of Orpheus is said to be the first thing ever that made Eumenides cry and neither the royal wife nor the ruler of the underworld could remain deaf to his pleas (v. 45-47). Verses 266-271 tell us of Pygmalion's great love. This is the continuation of the story I discussed before in relation to $\mathbf{T}, \mathbf{D}$ alliteration. A peculiar apostrophe precedes the story of Myrrha's incestuous love for her father Cinyras (v. 300-304):

dira canam: procul hinc natae, procul este parentes, aut, mea si vestras mulcebunt carmina mentes, 
desit in hac mihi parte fides, nec credite factum;

vel, si credetis, facti quoque credite poenam.

Myrrha realises that their close blood ties can only bring her injury. It would be better to leave her country, so that she could run away from her heinous passion. But she is imprisoned by love. She wants to see Cinyras, to touch him and talk with him (v. 338-343). Some verses later, the old nurse trembles from her old age and fear, throws herself down before her charge and alternates between placating and terrifying her. She threatens that if Myrrha does not tell her why she wanted to hang herself, she will report the whole incident (v. 414-418). The Mother of the Gods Cybele changes Hippomenes and Atalanta into lions (v. 700-705):

ex umeris armi fiunt, in pectora totum

pondus abit, summae cauda verruntur harenae;

iram vultus habet, pro verbis murmura reddunt.

The goddess Venus, driving her light swan-drawn chariot across the sky has not yet reached Cyprus when she hears from afar a cry of the dying boy and turns her birds in that direction (v. 718-721).

In Book XI, traditionally, the most frequent alliteration is $\mathbf{T}, \mathbf{D}$. In verses 22-27 we are told of Orpheus' death. Maenads stretched their bloody hands towards the Singer and ran to him as a flock of birds that see a night bird in broad daylight. Ovid uses here a simile. As a pack of hounds reaches a stag which is to die at dawn in the amphitheatre, so the Maenads leapt on Orpheus, striking him with green-leaved thyrsi. On the island of Lesbos, Phoebus stopped the snake which was about to bite Orpheus' head, torn away from the singer's body. Then he turned the snake into a hard rock with its maw wide open. The shade of the singer descended into the underworld and recalled all the places he had seen before (v. 59-62). In verses 75-79 we are told of Thracian women who by the will of Bacchus were affixed to the earth and unable to free themselves. Roots bound and imprisoned them despite their desperate struggle. In verses 374-376 we read about a bloodthirsty wolf that not only sated his hunger killing animals, but also slaughtered the whole herd in his madness. Some people were mortally wounded by the wolf and died in defence of the oxen. The shore, the coastal waters and the 
marshes which echoed with the mournful cries of the cattle became reddened with spilt blood. Any delay might prove pernicious, there is no time to spare for decision making. Another example refers to a sea storm. As if someone ripped Athos and Pindos from their foundations and thrown them into the open sea, so a huge wave tumbled forward and sank a ship in the depths (v. 554-556). A longer passage tells us of Alcyone's despair after she lost her husband Ceyx. Alcyone leaves the palace and sorrowfully returns to the shore where she had bidden her beloved goodbye and watched him depart. She recalls the events that took place there, looks at the sea and espies from afar something which resembles a human body carried by the waves (v. 710-717).

Let me start the discussion of clusters $\mathbf{M}, \mathbf{N}$ with verses 284-286. Ceyx, the ruler of Trachis in Thessaly, bids Peleus welcome. He says that in his kingdom even the commoners have the right to use all that the land offers. His good will and hospitality in this case is even greater, as Peleus is a man of great importance, famous name and splendid ancestry, being a descendant of Jove. Therefore, he should not waste time in supplication. The next example is found in verses 378-382. A farmer encourages people to take up arms, unite their strength and attack the wolf together. Peleus is not worried about the damage, but, bearing in mind the crime he committed, he realises that it is Nereid who brought this calamity upon him as a funeral sacrifice for her murdered son Phocus. Thus he ordered the men to put on their armour and take up their deadly spears. Ceyx cries out his wife Alcyone's name and wishes that the waves carry his body to the shore, so that her beloved hands could lay his dead body in the grave. He floats on the surface and keeps calling Alcyone's name, whenever the waves allow him to open his mouth. He whispers it even when they drown his face (v. 563-567). Alcyone confesses that her heart would have been more cruel than the sea if she tried to live on and if she wanted to conquer her despair. Yet these are not her desires and she will not abandon her husband. She will come to him as his companion and, though they will not be joined by a common urn, they will at least have one funeral inscription. If she cannot mix her bones with her husband's, then at least their names will be joined (v. 704-707).

In Book XII M, $\mathbf{N}$ alliteration becomes predominant. The first important clusters are found in verses 230-232. Magnanimous Theseus, who does not want his words to remain an unsubstantiated threat, pushes 
apart the Centaurs that stand in his way and snatches the girl from their mad hands. Gryneus lifts a huge altar, together with the burning sacrificial offerings, and launches it into the crowd of Lapiths, crushing two of them, Broteas and Orios. The narrator adds that the mother of Orios was Mycale, who supposedly used to draw down the horned new moon, overcoming its resistance (v. 260-264). In verses 316-318 we read that despite the horrendous noise Aphidas was sleeping soundly and could not be woken. In a limp hand he held a goblet filled with wine. A bit further the narrator recalls how the hunting spear thrown by Nessus' hand pierced the groin of Cymelus. We should not believe that Mopsus, Ampycus' son, could only predict future; at his hand fell bi-formed Hodites, trying in vain to speak, as his tongue was nailed to the floor of his mouth, and the floor of his mouth was nailed to his throat. Caeneus slew five centaurs (v. 453-461). Halesus, facing the enemy troops, shook his weapons, rode a circle on horseback and shouted into the empty space prideful words directed at Caeneus (v. 467-471). Centaur Monychus exclaimed that the whole tribe allow themselves to be bitten by one person who is only partially a man. And even if he is a true man, then centaurs, by acting slovenly, are what he was before. Do their huge bodies have any importance? Why do they possess double strength? What use is their dual nature that joined in their bodies two brave beings? They do not believe that their mother was a goddess and their father was Ixion who had enough courage to attack the mighty Juno. The centaurs allow the enemy, who is but half a man, to overcome them (v. 501-506).

Clusters with T, D alliteration are much less numerous. Cycnus tells Achilles that what counts is not being the son of a Nereid, but being a man who has power over Nereus and his daughters, as well as the whole ocean. Once he finishes what he has to say, he hurls a spear at Achilles, but it gets stuck in a bend of his shield (v. 93-96). Charaxus' hair, violently set aflame, burnt like a field of corn, while his blood boiled in the wound, and hissed like red-hot iron when the smith takes it out from the fire with curved tongs and plunges it into a tub, where the metal sizzles and whistles, immersed in warm water (v. 276-279):

terribilem stridore sonum dedit, ut dare ferrum igne rubens plerumque solet, quod forcipe curva 
cum faber eduxit, lacubus demittit; at illud

stridet et in tepida submersum sibilat unda.

Dictys fell into a precipice, crushing with his weight an enormous ash tree and spilling his innards on a jutting stump. Aphareus, wanting to avenge his death, ran over and attempted to hurl a rock at Theseus, but the son of Aegeus struck him with oaken club and broke his massive elbow bone. Not stopping to finish his downed enemy, he leaped onto Bianor's back, the tall centaur who had never before carried anyone but himself (v. 340-346).

In Book XIII the most frequent alliteration is again T, D. I shall start the discussion with verses 36-39. During the debate over Achilles' armour, Ajax asks a rhetorical question: who seems more worthy, a man who took up arms only in the last possible moment and eschewed fighting, pretending to be mad, or another, much more clever than him, the son of Nauplius, who, alas, to his own detriment, discovered Ulysses' deceit and dragged the coward to the battle which he had tried to avoid. In the next part of his speech Ajax recalls that Hector arrived on the battlefield and led the gods into the fray. Wherever he went, he instilled terror so great that not only Ulysses, but even the most courageous men quaked with fear (v. 81-84). In his reply, Ulysses asks why Ajax did not demand to have Troy destroyed. Why did he not stop the fleeing army? Not only did he fail in stopping the retreat, but he was also shamelessly running away himself and readying the sails on his ship. Ulysses saw that the Greeks had fallen to madness, as all they wanted to do was to leave Troy they had already conquered. He shouted at them. What will they bring back home, apart from shame, after ten years of war? With these words Ulysses stopped the Greeks' flight and turned them back from their ships. Since then all the brave deeds of Ajax were in fact achieved thanks to Ulysses, who stopped him from running away (v. 220-230; 236-239). Concluding his speech, Ulysses says that if there is anything the Greeks lack in order to destroy Troy, then they should remember him. If they do not grant him Achilles' armour, then they should give it to Minerva (v. 378-381). The next alliterated passage tells us of the fall of Troy: the fires had not died down yet, when the blood of Priam was spilled on Jove's altar and Phoebus' priestess, dragged by her hair, raised her helpless arms to the skies. The victorious Greeks claimed as 
enviable spoils the Dardanian women, who embraced the statues of their local gods and took shelter in the burning temples (v. 410-412). In verses 521-524 Hecuba confesses that death had brought Priam his happiness, for he did not live to see his daughter Polyxena sacrificed to appease the dead: he had lost his kingdom and his life at the same moment. Nonetheless, Polyxena will receive a decent burial and she will be laid down in the tomb of her ancestors. Another longer alliterated passage is also about Hecuba. Forgetting her old age, yet bearing in mind her vengeance, she ran to Polymestor, Polydorus' killer, and demanded an audience. She pretended that she wanted to show him the place where she had hidden gold for her son, to be given to him. The Thracian believed her and followed her to a secluded place, driven by greed. There, he encouraged her to trust him with the hoard. He swore that everything she would give him would be passed to her son, similar to the treasure she had entrusted him with previously. She looked at him with grim eyes when he swore falsely. Finally, when her rage surged in her as a tidal wave, she called her fellow Trojan women for aid and tore the captured king's deceitful eyeballs with her own fingers (v. 551-561). In verses 580-582 and 589-594 we are told the story of Aurora's grief. She was torn by sorrow and despair after the death of Memnon, who had fallen pierced by Achilles' spear on the Phrygian plain. She saw him passing away and the rosy hue of her face paled, while the sky became shrouded with clouds. Aurora begged Jove for help. She told him she came thither not to ask for new temples, feasts and altars. If he were to consider how important her service had been, then he would agree that she merited a reward. Yet what she wanted at that moment was not honour for herself, but for her fallen son (v. 589-594). The last passage is about Galatea. She had just finished her story and the Nereids dispersed, swimming away amid the placid waves. Scylla, who was afraid to venture into the deeps, returned, took off her robe and wondered over the dry sand or, when she grew tired, found a sheltered cove and refreshed her body in the calm waters (v. 899-904).

I shall start the account of $\mathbf{M}, \mathbf{N}$ alliteration with verses $95-100$. Ajax tries to convince the Greeks that the armour merits greater respect than he does, while the glory belongs to them both. It is the armour that needs Ajax, not vice versa. Let Ulysses see if he can compare his deeds, such as killing Rhesus and craven Dolon, capturing Helenus, the 
son of Priam, or stealing Palladium, with these of Ajax. Ulysses, on the other hand, claims (v. 254-260) that there is no need for him to speak of how he destroyed with his own sword the troops of Sarpedon, or how he slaughtered numerous Lycian heroes. In the next part of his speech (v. 364-368) Ulysses attempts to prove that though Ajax knows how to fight, it is the Atrides who tell him when to fight. Ajax supports the Greeks with his strength, Ulysses, with his intelligence. Ulysses is better than Ajax, as much as a captain is better than a mere oarsman, or a general is better than a foot soldier. In verses 462-465 we find out that Polyxena wants the Greeks to hide her death from her mother. Yet the mother finds out how her daughter was sacrificed and is distraught with grief. We are told that Hecuba should not lament over her daughter's death, but rather over her own unhappy life. The pain of Anius after he lost his children is described in verses 645-647. In another long passage, Polyphemus promises Galatea that in the autumn she will be gathering dogberries and juicy plums. If she becomes his wife, she will have chestnuts and the fruit of strawberry tree aplenty. She will be able to pick all the types of fruit from the trees in his domain. Polyphemus boasts that he is the owner of a large herd; many of his cattle walk free in the valleys, many stand in the caves. Galatea will find in his homestead not only everyday pleasures and small gifts, such as deer, hares, goats, a couple of wild pigeons or a nest taken off the top of a tree; one day he encountered on the mountain peak the young of a bear, two little cubs so closely resembling each other that they were undistinguishable. Therefore Galatea's luminous head should emerge out of the blue deeps of the sea. Let her come and not spurn his gifts. Recently he had looked into a water mirror and thought himself quite becoming. Even Jove is not taller than Polyphemus (v. 818-821; 831-834; 838-841).

I shall now discuss Book XIV. Here $\mathbf{M}, \mathbf{N}$ alliteration becomes the most frequent again. Circe strives for Glaucus' love. She confesses that though she is a goddess, daughter of the radiant Sun, mighty in her magic and powerful herbs, she desires only to belong to him. He should spurn the one who spurns him and return the love of another, who loves him (v. 33-35). In verses 138-144 we are told about the wish expressed by Sybil of Cumae. She pointed at a pile of sand and asked Phoebus for as many years of life as there were grains in the pile. Yet she forgot to ask at the same time to be granted youth for all these years. The god 
overlooked her folly and promised to give her youth, if she surrendered to him. She rejected him, preferring to remain a virgin. Now, her happy years have passed and old age came with trembling steps. Unlike others, she will have to bear it for a long time. There will come a day when the passage of time will wither her body almost to nothing and her limbs, emaciated by age, will shrink. Nobody will be able to imagine she was once loved and desired by a god (v. 147-149). In verses 165-168 we are given the story of Achaemenides, a Greek saved by Trojans. Full of emotion, he confesses that he would sooner see Polyphemus again, with his maw dripping human blood, than place his own home and Ithaca above the Greek ship or esteem Aeneas any less than his own father. Achaemenides recalls how he was paralysed with fear when he looked at Polyphemus' face, still dripping with blood, at his cruel hands, at his gouged eye and at his chin and body coated in caked human gore. He saw death before his eyes, but that was the least of his worries. He fancied that Polyphemus was already catching and devouring him (v. 200204). In verses 262-265 we listen to a fragment of Macareus story about his meeting with Circe. She was sitting in a beautiful room, on a splendid throne, dressed in shining robe, over which a golden cloak was thrown. Her maids were nereids and nymphs. They did not spin wool, nor worked the threads with nimble fingers. Instead, they busied themselves with arranging plants, gathering the flowers and multi-coloured herbs, thrown around in disarray, and putting them in separate baskets. Macareus tells as well the story he heard from the servant of Circe, one of four girls who helped with the magical rituals. The nymph showed him a statue of white marble, representing a young man with a woodpecker on his head (v. 310-314). In verses 427-430 the narrator tells us the story of Canens searching for her husband Picus. Exhausted by grief and long travel she finally came upon the river Tiber and lay down on its wide bank. There, drowning in tears, she faintly hummed of her worries, like a dying swan that sings its funeral song. At last her body, wrecked by pain, transformed into water and slowly diffused in the light air. Macareus' story ends with a short epitaph engraved on a marble urn (v. 441-444):

HIC $\cdot$ ME $\cdot$ CAIETAM $\cdot$ NOTAE $\cdot$ PIETATIS $\cdot$ ALUMNUS

EREPTAM $\cdot A R G O L I C O \cdot Q U O \cdot D E B U I T \cdot I G N E \cdot C R E M A V I T$. 
Acmon claims that should Venus hear all that he says and hate him for it, they can nonetheless spurn her hate, for she already hates all the companions of Diomedes (v. 491-494). In verses 503-511 the narrator tells us about the metamorphosis of people into birds. Acmon's feet suddenly expanded, his toes getting larger, then his face became a hard beak, sharply curved at the end. This transformation was witnessed by astonished Lycus, as well as Idas, Rhexenor, Nycteus and Abas. While they were marvelling at his metamorphosis, they assumed the same shape. If someone asks what species these birds belong to, the answer is they resemble most closely white swans. Another passage describes the fall of Ardea. Once the foreign sword wrecked it and hot ashes covered its houses, out of the ruins flew a hitherto unknown bird and flapped its wings, shaking off the ashes. Its voice was lugubrious, its shape skeletally thin, its plumage mortally pale; in short, he embodied all that is typical of a conquered city. It bore the same name as the place from which he was born, and his wings wept over the fate of Ardea (v. 578-580). In verses 702-706 we read about the love of Iphis for Anaxarete. Long did he struggle with himself and when his mind could no more curb his passion he came timidly to her doorstep and confessed his love to her nurse. He begged the old woman, in the name of hope that she held for her nursling, to help him gain her favour. He tried to win over her numerous attendants with flattery. Iphis remonstrates with Anaxarete, exclaiming that the love he has for her will not end before his life does, therefore he has to lose both lights at the same time. She will not learn of his death from a rumour: he will come to her himself, his presence visible, so that she can feast her merciless eyes on the sight of his dead body (v. 724726). In the end, after gazing at dead Iphis carried in a funeral procession, Anaxarete slowly turned into stone, for her heart had already been long made of it. The narrator adds that in Salamis one can still see the stone figure of the girl and a temple dedicated to Gazing Venus (Venus Prospiciens) (v. 760-762). In the next passage, the narrator recalls that near the temple of Janus there was a place inhabited by Ausonian Naiads, where a cold spring streamed forth. The goddess asked the nymphs for help. They did not deny her just request and opened the veins of their spring (v. 787-789). The last of the important passages in this book refers to Romulus. Mars, having taken off his iron helmet, spoke to the father of gods and people. He argued that as Rome was standing on solid 
foundation and its fate no longer depended solely on its ruler, the time came for Jove to reward him. He should be taken from earth and placed in the heavens. Once, during the council of gods, Jove told Mars that Romulus would be the one who carries him into the blue skies. Let these words come true (v. 809-813).

I will now discuss examples from Book $\mathrm{XV}$, which is the last one. Here again the most frequent are clusters with $\mathbf{M}, \mathbf{N}$ alliteration. In verses 44-47 the narrator tells us about the old custom practiced in the courts, where black stones were used to pronounce the defendant's guilt, while white ones to proclaim his innocence. When the son of Alemon of Argos was judged, every stone thrown mercilessly into the urn was black. Yet when the urn was turned over to count the Stones, they all changed their colour from black to white. This way Heracles turned the tide of the vote and Alemon's son was freed. Pythagoras teaches that wild animals sate their hunger with meat, yet not all of them. Horses, sheep and cattle eat grass. Only the beasts which have fierce and cruel nature, such as Armenian tigers and angry lions, bears and wolves, delight in bloody feasts (v. 83-87). In verses 194-198 Pythagoras points out that Phoebus's visage, when in zenith, is white, because there the ether is more pure and distanced from the pernicious influence of the earth. Also the shape of Diane, the goddess of night, undergoes changes: whenever she increases, she is smaller the preceding day, whenever she decreases, she is larger:

nec par aut eadem nocturnae forma Dianae

esse potest umquam semperque hodierna sequente, si crescit, minor est, maior, si contrahit orbem.

In the next part of his speech (v. 257-258; 309-314; 350-355) the philosopher claims that although things may move here and there, when the final reckoning comes, the whole remains unchanged. He is convinced that nothing can last long in the same shape. Even water can both give and take different forms. In the middle of a day the spring of the horned Ammon is cold, but at dawn and dusk it becomes warm. It is rumoured that the Athamanians put the wood on fire by pouring water over it, when the moon is new. If the tarry substances can start a fire and the yellow sulphur burns almost without any smoke, then, when earth no longer feeds the flames with oily fuel, exhausted after many years, 
earth will lose the ability to support the voracious element and the fire, incapable of withstanding its famine, will desert the empty caverns. In verses 431-434 the philosopher teaches that times change and some nations grow in strength, while others decline. Apparently, the Rome of the Dardanians has now the time to rise, providing solid foundations for the future power on the banks of the Tiber, the river which is born in the Apennines. This Rome, while growing, changes its shape. One day it will become the capital city of the whole world. In the next part of his lecture (v. 450-459) Pythagoras reminisces about the prophecy given by Helenus to Aeneas, when he was fleeing with his lares and penates. The philosopher rejoices that the walls of Rome are already growing and that the Greeks defeated the Phrygians only to the former's benefit, for no city will ever be greater. He adds that the sky and everything below it constantly changes its shape, so does the earth and all things that exist on it. People are also part of the universe, for they are built not only of matter, but also of winged spirit. Therefore, they can enter the bodies of wild animals and live imprisoned in the shape of cattle. He provides further examples. Hippolytus says that he lives in the grove of Aricia and, as one of the minor gods, finds shelter under the care of goddess Diana, being one of her subjects (v. 545-546). In verses 555-566 the narrator tells the story of the Tyrrhenian farmer who saw how a lump of earth in the middle of the field started to move of its own accord, though nobody touched it, and then took a human shape, losing its former nature. Finally, it opened her freshly shaped lips to prophesize future events. The local people call him Tages, he who first taught the Etruscans how to divine what is to come. Hippolytus was amazed at seeing him, the same way that Romulus was astonished when he saw his spear, which was driven into the ground on Palatine Hill, suddenly sprout green leaves and stand on its new root, instead of the iron point it formerly possessed. It was no longer a spear, but a supple tree which unexpectedly shared its shadow with those who admired the unusual metamorphosis. The narrator adds that very similar astonishment was experienced by Cipus, when he saw horns growing out of his head amid the river's waters. Another passage (v. 724-726) refers to the snake called the god of Epidaurus. When the sea calmed down, the snake abandoned the paternal altars of Antium and, having enjoyed the hospitality in his father's temple, he slid over the sandy shore, rustling his scales, then slithered up the rudder, 
rested his head on the ship's high sternpost and stayed there until they arrived at Castrum, the sacred seat of Lavinium and the mouth of Tiber. In verses 750-751 the narrator states that out of all Julius Caesar's accomplishments none is greater than the fact that he became father to such a great son:

\section{neque enim de Caesaris actis}

ullum maius opus quam quod pater exstitit huius.

Next, he poses a rhetorical question (v. 752-759) what is more important: to conquer the Britons, a nation surrounded by sea, to lead victorious ships up the seven-mouthed Nile, the papyrus-bearing river, to subjugate the Libyan Juba and bring under the Roman rule Pontus, the city puffed up with the mighty name of Mithridates, to deserve numerous triumphs, yet celebrate only few, or to give the world such a great man. Under his rule the gods have bestowed upon humankind many favours. In verses 837-842, which constitute a part of Augustus' panegyric, Jove states categorically that Augustus will not enter the heavenly abode and reach his fellow stars until he grows old and equals Nestor in his age. Let Venus separate the spirit from the body of the murdered Caesar and make it a shining light, so that he, as divine Julius, may always gaze from his lofty home at Capitol and Roman forum. I will now proceed to discuss clusters with multiple T, D alliteration. I will start with the analysis of verses 24-29. They contain the story of Myscelus, son of Alemon of Argos. When he was laying in deep sleep, Hercules spoke in his dream and ordered him to leave his home country and seek the rocky bed of the faraway river Aesar. He threatened Myscelus with dire consequences in case of disobedience. The god and the dream both disappeared suddenly. The son of Alemon got up and recalled all that he saw in his dream. For a long time he debated with himself: the god ordered him to leave, yet the laws of his country forbade him to do that, for everyone who desired to change his home country was punished by death. In verses 199-205 we read some further remarks of Pythagoras. He observes that the year takes on four different shapes, similar to the human life. In early spring it is delicate as a baby and resembles a small child. The vegetation is then bright green, full of juices, and, though it remains yet feeble and weak, it already fills the farmers with joyful hope. Everything is in bloom, the 
rich fields are painted with myriads of colourful flowers, but the leaves still lack their virility (virtus). In verses 270-272 we can read further teachings of Pythagoras on the unusual changes in the world of nature. In one place Nature willed new springs to come forth, in another, to dry out:

hic fontes natura novos emisit, at illic clausit, et antiquis tam multa tremoribus orbis flumina prosiliunt aut excaecata residunt.

As a result of movements in the bowels of the earth rivers can either find their way up to the surface or dry out and stop flowing. In the next passage (v. 411-415) the philosopher of Samos tells us about an animal (chameleon) that feeds on wind and air and immediately takes on the colour of the thing it touches. The conquered India provided Bacchus, crowned with vine, with lynxes. It was said that every drop of their urine turned into pebble, solidifying upon contact with the air. The teachings of Pythagoras contain many further examples of this alliteration. How impiously does prepare himself to shed human blood he who slits the throat of a calf with a knife, who witnesses unmoved the terrified bellows, or who can murder a billy goat, or eat the bird he raised and fed himself! (v. 463-469). In another longer passage (v. 683-696) the snake-god gives the descendants of Aeneas a favourable sign: moving his crest he assures them of his grace and he hisses twice with his twitching tongue. Then he slithers down the smooth steps and, turning back, looks at his former altar which he is to abandon, and gives a final farewell to his temple, where he resided for so long. Thence he crawls on, enormous, over the path strewn with flowers, and, rolling his coils, travels through the city until he reaches the harbour, sheltered by its curved embankment. There he stops and it seems as if he is graciously saying farewell to his retinue and the accompanying crowds, then he settles aboard the Ausonian ship. Under the god's weight the vessel sank deeper into the waves. The Romans are overjoyed: after sacrificing a bull on the shore, they crown the ship with flowers and set out for the open sea. In the following verses (701-704) we read how the ship passes the shores of Latium, famous for Juno's temple, and Scylaceum. It leaves behind Iapygia and avoids the Amphrisian rocks to the larboard, the Cocinthius 
promontory to the starboard. In verses 760-767 the narrator attempts to convince the reader that Julius Caesar must have become a god, so that his son was not born from mortal seed. The mother of Aeneas, when she noticed that her son was in mortal danger and that an armed conspiracy was formed against him, asked the gods for help. She said that a trap was assiduously prepared against her and the conspirators treacherously attacked the only descendant of Trojan Iulus still alive, all that she had left. In the last of the passages I analyse here (v. 829-835) Jove in vaticinium ex eventu shows the goddess Venus the great achievements of Augustus. Every inhabited country on earth will be his property and his rule will extend even over the sea. Once he introduces peace on earth, he will turn his attention to the civic legislation and institute just laws. By his own excellent example he will instil better morals in the depraved society.

In conclusion I would like to observe that the two most important alliterations, T, D and $\mathbf{M}, \mathbf{N}$, play a variety of roles in books IX-XV. Naturally, above all they are used to describe the metamorphoses, e.g. Iphis changing into a man, Hippomenes and Atalanta into lions, Dryope into a tree, Acmon into a bird, Canens into water, Picus into a woodpecker, Anaxarete into stone, a lump of earth into Tages, the spear of Romulus into a green tree, Olenus and Lethaea into two rocks, and Thracian women into trees. They express great passions in a very suggestive manner, e.g. the unnatural love of Myrrha to her father Cinyras, the love of Byblis to her brother, the love of Pygmalion to a statue of a beautiful woman, the love of Polyphemus to Galatea, the worry Venus feels for Aeneas, the fear of Achaemenides, the despair of Orpheus, the struggle of Achelous with Heracles, the rape of Deianira, the courage of Hippomenes, the grief of Venus after the death of Adonis, the grief of Aurora after the death of Memnon, Alcmene's confession to Iole, the wishes of Sybil of Cumae. Many times, the alliteration clusters describe the death of the protagonists, e.g. of Nessus and Heracles, Eurydice, Orpheus, Hyacinthus, Polyxena, and Hecuba. Also the teachings of Pythagoras in Book XV abound in alliterations. They can be found in the description of the apotheosis of Romulus and Augustus, as well as in the passage on Heracles' immortality. They feature prominently in the description of the battle of Lapiths and Centaurs, as well as the fight of Ajax and Hector for Achilles' armour. Finally, they describe the elements, such as the flood or sea storm, and powerful animals, such as a bloodthirsty wolf or the snake-god, favourable to Romans. 


\section{BIBLIOGRAPHY}

\section{Primary sources:}

P. Ovidii Nasonis Metamorphoses, 1991, W. S. Anderson (ed.), Leipzig.

Owidiusz, 1995, Metamorfozy, transl. A. Kamieńska, S. Stabryła, S. Stabryła (ed.), Wrocław-Warszawa-Kraków.

\section{Secondary sources:}

Ahl F., 1985, Metaformations: Soundplay and Wordplay in Ovid and Other Classical Poets, Ithaca.

Clarke W. M., 1976, 'Intentional Alliteration in Vergil and Ovid', Latomus 35, pp. $276-300$.

Fantham E., 2004, Ovid's Metamorphoses, Oxford.

Galinsky G. K., 1975, Ovid's Metamorphoses. An Introduction to the Basic Aspects, Oxford.

Herescu N. I. (ed.), 1958, Ovidiana. Recherches sur Ovide, Paris.

Korpanty J., 2014, Studies in the Sound Instrumentation in Latin Literature, Kraków.

Otis B., 1970, Ovid as an Epic Poet, $2^{\text {nd }}$ ed., Cambridge.

Solodow B., 1988, The World of Ovid's Metamorphoses, Chapel Hill - London. 